\title{
Litoricolaceae fam. nov., to include Litoricola lipolytica gen. nov., sp. nov., a marine bacterium belonging to the order Oceanospirillales
}

Correspondence
Jang-Cheon Cho
chojc@inha.ac.kr

The order Oceanospirillales within the class Gammaproteobacteria (Garrity et al., 2005a) is largely based on $16 \mathrm{~S}$ rRNA gene sequence phylogeny. The order encompasses a diverse range of Gram-negative bacteria that are generally halophilic or halotolerant, rod-shaped, motile (except for the members of the genus Alcanivorax) and chemoheterotrophic. The order currently contains five families with validly published names and one that remains to be validly published: Oceanospirillaceae (Garrity et al., 2005b), Alcanivoracaceae (Golyshin et al., 2005), Halomonadaceae (Franzmann et al., 1988), Hahellaceae (Garrity et al., 2005c), Oleiphilaceae (Golyshin et al., 2002) and 'Saccharospirillaceae' (Labrenz et al., 2003). In this study, we report on the isolation and taxonomy of a single strain that could not be assigned to any of the defined families in the order Oceanospirillales.

The GenBank/EMBL/DDBJ accession number for the $16 \mathrm{~S}$ rRNA gene sequence of strain IMCC $1097^{\top}$ is EF176580.

Transmission electron micrographs of cells of strain IMCC $1097^{\top}$ are available as a supplementary figure with the online version of this paper.
A sample of coastal seawater was collected, at a depth of $10 \mathrm{~m}$, near Goseong, East Sea, Korea $\left(38^{\circ} 20^{\prime} \mathrm{N} 128^{\circ} 33^{\prime}\right.$ E), in June 2005. An aliquot $(100 \mu \mathrm{l})$ of the seawater sample was spread onto an oligotrophic medium, R2A agar (Difco) diluted 1:10 (v/v) with aged seawater (referred to as 1/10R2A), and the agar plates were incubated aerobically at $20{ }^{\circ} \mathrm{C}$ for 1 month. Strain $\mathrm{IMCC} 1097^{\mathrm{T}}$, initially grown on 1/10R2A, was further purified on marine agar 2216 (MA; Difco) after growth of the strain at $20{ }^{\circ} \mathrm{C}$ for 2 weeks. After the optimum growth temperature for the strain had been determined, cultures were maintained routinely on MA at $25{ }^{\circ} \mathrm{C}$.

The almost-complete sequence of the 16S rRNA gene (1483 bp) for strain IMCC $1097^{\mathrm{T}}$ was obtained as described previously (Cho \& Giovannoni, 2003). Phylogenetic analyses, including multiple alignment of 16S rRNA gene sequences and generation of phylogenetic trees, were performed using the ARB package (Ludwig et al., 2004) and PAUP ${ }^{*}$ (Swofford, 2002) as described by Cho \& Giovannoni (2006). Preliminary sequence comparisons against the 16S rRNA gene sequences deposited in 
GenBank and the Ribosomal Database Project showed that the strain belonged to the class Gammaproteobacteria. The sequence similarity of strain $\mathrm{IMCC} 1097^{\mathrm{T}}$ with respect to recognized species within the Gammaproteobacteria was very low: no species with validly published names showed more than $90 \%$ sequence similarity. Comparative analyses of $16 \mathrm{~S}$ rRNA gene sequence similarity based on manually aligned sequences in the ARB database showed that the most closely related type strains of species with validly published names included Saccharospirillum impatiens DSM $12546^{\mathrm{T}}$ (89.3\%), Oleiphilus messinensis DSM $13489^{\mathrm{T}}(88.7 \%)$, Reinekea marinisedimentorum DSM $15388^{\mathrm{T}} \quad(88.2 \%)$, Alcanivorax borkumensis ATCC $700651^{\mathrm{T}}(87.6 \%)$ and Zooshikella ganghwensis DSM $15267^{\mathrm{T}}(87.6 \%)$. The above species all belong to the order Oceanospirillales; however, they represent five different families in the order, which indicates a unique phylogeny for strain IMCC $1097^{\mathrm{T}}$. In all of the phylogenetic trees, generated using three different algorithms (Fig. 1), strain IMCC $1097^{\mathrm{T}}$ formed a robust monophyletic clade with uncultured bacteria $\mathrm{F} 3 \mathrm{C} 13$ (99.5\% sequence similarity; Prabagaran et al., 2007) and CHAB-V-35 (97.6\% sequence similarity; Schäfer et al., 2000). This monophyletic clade containing the novel isolate was clearly distinguishable from other families within the order Oceanospirillales. In the maximumlikelihood and neighbour-joining trees, the clade containing strain $\mathrm{IMCC} 1097^{\mathrm{T}}$ formed a larger clade with $Z$. ganghwensis DSM $15267^{\mathrm{T}}$ (Fig. 1). However, this relationship between $\mathrm{IMCC} 1097^{\mathrm{T}}$ and $Z$. ganghwensis was not found in the maximum-parsimony tree, and, moreover, the bootstrap percentages obtained did not support monophyletic relationships for the clade. According to our phylogenetic analyses, the order Oceanospirillales and the families Oceanospirillaceae and Hahellaceae had polyphyletic properties. In spite of incomplete phylogenetic resolution of the order Oceanospirillales and the class Gammaproteobacteria, the very low sequence similarities $(<90 \%)$ and the distant relationships between strain IMCC $1097^{\mathrm{T}}$ and other families within the order Oceanospirillales suggested that the strain represented a novel genus within a novel family in the order Oceanospirillales.

Phenotypic and chemotaxonomic characteristics were determined using MA at $25{ }^{\circ} \mathrm{C}$, unless otherwise indicated. Cellular morphology was examined with transmission electron microscopy (CM200; Philips). Exponentially grown bacterial cultures were washed with sodium cacodylate buffer twice and negatively stained with $2 \%$ phosphotungstic acid (pH 7.0-7.2) on Formvar-coated copper grids. Cell size and morphology were also determined using phase-contrast microscopy and epifluorescence microscopy (Nikon 80i) with 4',6-diamidino-2phenylindole (DAPI) staining. Motility was tested from wet mounts of exponential-phase cells. The presence of poly- $\beta$ hydroxybutyrate granules was checked using epifluorescence microscopy after staining of the cells with Nile blue A (Ostle \& Holt, 1982). Colony morphology, size and colour were examined using cultures grown aerobically on MA for
1 week. The capacity of strain $\mathrm{IMCC} 1097^{\mathrm{T}}$ for anaerobic growth was tested using the MGC anaerobic system with AnaeroPACK Anaero (Mitsubishi Gas Chemical) with cells incubated for up to 3 weeks. A catalase test was performed by adding $3.0 \%$ hydrogen peroxide to fresh colonies, and oxidase activity was determined using Kovács solution (Kovács, 1956). The temperature range and optimum were tested from 4 to $42{ }^{\circ} \mathrm{C}$. The $\mathrm{pH}$ range and optimum were examined from $\mathrm{pH} 4.0$ to 12.0 . The $\mathrm{NaCl}$ concentrations and optimum for growth were determined in $\mathrm{NaCl}$-free artificial seawater medium (ASW; basic formula, with $\mathrm{NaCl}$, containing the following, $\mathrm{l}^{-1}: 19.45 \mathrm{~g} \mathrm{NaCl}, 5.9 \mathrm{~g}$ $\mathrm{MgCl}_{2} .6 \mathrm{H}_{2} \mathrm{O}, 3.24 \mathrm{~g} \mathrm{MgSO}_{4} .7 \mathrm{H}_{2} \mathrm{O}, 1.8 \mathrm{~g} \mathrm{CaCl}_{2} .2 \mathrm{H}_{2} \mathrm{O}$, $0.55 \mathrm{~g} \mathrm{KCl}, \quad 0.16 \mathrm{~g} \quad \mathrm{NaHCO}_{3}, \quad 0.08 \mathrm{~g} \mathrm{KBr}, \quad 0.034 \mathrm{~g}$ $\mathrm{SrCl}_{2} .6 \mathrm{H}_{2} \mathrm{O}, 0.022 \mathrm{~g} \mathrm{H}_{3} \mathrm{BO}_{3}, 0.008 \mathrm{~g} \mathrm{Na}_{2} \mathrm{H}_{2} \mathrm{PO}_{4}, 0.004 \mathrm{~g}$ $\mathrm{Na}_{2} \mathrm{SiO}_{3}, 0.0024 \mathrm{~g} \mathrm{NaF}, 0.0016 \mathrm{~g} \mathrm{KNO}_{3}$ ), supplemented with $5.0 \mathrm{~g}$ peptone, $1.0 \mathrm{~g}$ yeast extract and $0-15 \%(\mathrm{w} / \mathrm{v})$ $\mathrm{NaCl}$. Other biochemical tests were performed using API 20NE and API ZYM (bioMérieux) according to the manufacturer's instructions, by inoculating the cells into ASW medium. The utilization of various compounds as sole carbon sources was tested as described in a previous study (Cho \& Giovannoni, 2003), using custom-made 48well microtitre plates containing 47 different carbon compounds (listed in the species description) at a final concentration of $0.02 \%(\mathrm{w} / \mathrm{v}$ or $\mathrm{v} / \mathrm{v})$ in ASW medium. The microtitre plates were incubated aerobically at $25{ }^{\circ} \mathrm{C}$ for 1 week, and cellular growth in each well was screened using epifluorescence microscopy with DAPI staining. Susceptibility to the following antimicrobial agents was determined (using the diffusion plate method): tetracycline, $30 \mu \mathrm{g}$; ampicillin, $10 \mu \mathrm{g}$; kanamycin, $30 \mu \mathrm{g}$; chloramphenicol, $25 \mu \mathrm{g}$; erythromycin, $15 \mu \mathrm{g}$; gentamicin, $10 \mu \mathrm{g}$; penicillin G, $10 \mu \mathrm{g}$; streptomycin, $10 \mu \mathrm{g}$; vancomycin, $30 \mu \mathrm{g}$; and rifampicin, $50 \mu \mathrm{g}$. The DNA G $+\mathrm{C}$ content of strain IMCC $1097^{\mathrm{T}}$ was analysed by using HPLC according to Mesbah et al. (1989). Cellular fatty acid methyl esters were prepared from cultures grown on MA at $25{ }^{\circ} \mathrm{C}$ for 1 week, and analysed according to the instructions of the Microbial Identification System (MIDI) by the Korean Culture Center of Microorganisms.

Cells of strain $\mathrm{IMCC} 097^{\mathrm{T}}$ were Gram-negative, nonpigmented, chemoheterotrophic, non-motile, facultatively aerobic, short rods that required $\mathrm{NaCl}$ for growth. The colonies were $0.05 \mathrm{~mm}$ in diameter, increasing to $1 \mathrm{~mm}$ after a prolonged incubation period of 3 weeks. The taxonomic characteristics of the strain are described in detail in the genus and species descriptions. Several phenotypic and genomic characteristics clearly differentiated strain IMCC $1097^{\mathrm{T}}$ from phylogenetically distantly related genera in the families Hahellaceae, Oceanospirillaceae, Oleiphilaceae, 'Saccharospirillaceae' and Alcanivoracaceae (Table 1). The strain was differentiated from the genera Zooshikella and Hahella on the basis of several characteristics, including pigmentation, flagellar motility, catalase activity and DNA G+C content. The major cellular fatty acids detected in strain $\mathrm{IMCC} 1097^{\mathrm{T}}$ were 


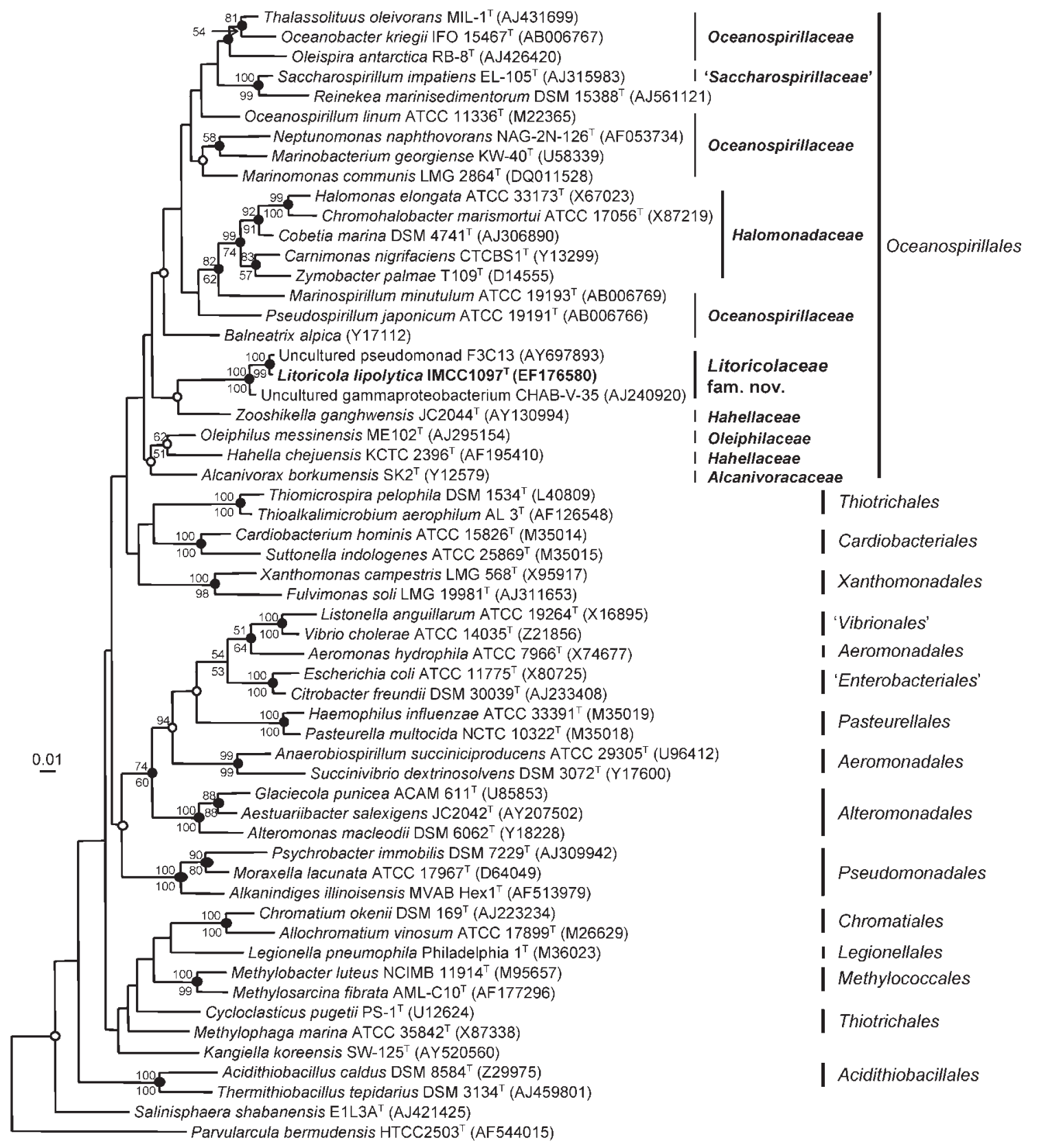

Fig. 1. Maximum-likelihood phylogenetic tree, based on 16S rRNA gene sequences, showing the distant relationships between strain IMCC $1097^{\top}$ and representatives of the class Gammaproteobacteria. Bootstrap percentages (above $50 \%$ ) from both neighbour-joining (above nodes) and maximum-parsimony (below nodes) approaches are shown. Filled and open circles at each node respectively indicate nodes recovered reproducibly by all treeing methods or by two treeing methods. Each family and order in the Gammaproteobacteria is indicated. Bar, 0.01 substitutions per nucleotide position.

$\mathrm{C}_{16: 1} \omega 7 c$ and/or iso- $\mathrm{C}_{15: 0} \quad 2-\mathrm{OH} \quad(42.8 \%), \mathrm{C}_{18: 1} \omega 7 c$ (20.6\%), $\mathrm{C}_{10: 0} 3-\mathrm{OH}(14.1 \%)$ and $\mathrm{C}_{16: 0}(6.5 \%)$, and the overall fatty acid composition was different from that of other genera of the order Oceanospirillales (Table 2). The presence of $\mathrm{C}_{10: 0} 3-\mathrm{OH}$ and $\mathrm{C}_{12: 1} 3-\mathrm{OH}$ and the absence of

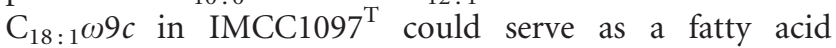
signature for differentiating the strain from the members of the genera Zooshikella, Hahella and Reinekea (the fatty acid profiles of which were obtained from biomass grown on MA). On the basis of the above results, strain IMCC $1097^{\mathrm{T}}$ cannot be characterized as a member of any of the known genera within the order Oceanospirillales.

It is evident from the low levels of 16S rRNA gene sequence similarity $(<90 \%)$, the unique branching patterns in the phylogenetic analyses and the phenotypic characteristics 
Table 1. Differential characteristics of strain IMCC $1097^{\top}$ and other marine bacteria related to the order Oceanospirillales

Taxa: 1, IMCC1097 ${ }^{\mathrm{T}}$; 2, Zooshikella (data from Yi et al., 2003); 3, Hahella (Lee et al., 2001; Baik et al., 2005); 4, Reinekea (Romanenko et al., 2004); 5, Oleiphilus (Golyshin et al., 2002); 6, Saccharospirillum (Labrenz et al., 2003); 7, Alcanivorax (Bruns \& Berthe-Corti, 1999; Fernández-Martínez et al., 2003; Liu \& Shao, 2005; Yakimov et al., 1998). +, Positive ; -, negative ; v, variable among species; ND, no data available. All organisms are positive for oxidase activity.

\begin{tabular}{|c|c|c|c|c|c|c|c|}
\hline Characteristic & 1 & 2 & 3 & 4 & 5 & 6 & 7 \\
\hline Cell shape ${ }^{*}$ & SR & $\mathrm{CR}$ & LR & $\mathrm{R}$ & $\mathrm{TR}$ & S & $\mathrm{R}$ \\
\hline Pigmentation & - & + & + & - & - & - & - \\
\hline \multicolumn{8}{|l|}{ Growth at/with: } \\
\hline $4{ }^{\circ} \mathrm{C}$ & - & - & - & + & - & + & $\mathrm{v}$ \\
\hline $40{ }^{\circ} \mathrm{C}$ & - & + & + & - & - & + & $\mathrm{V}$ \\
\hline $8 \% \mathrm{NaCl}$ & + & - & + & - & + & + & + \\
\hline Catalase activity & - & + & + & + & + & + & + \\
\hline Flagella & - & + & + & + & + & + & $\mathrm{V}$ \\
\hline $\begin{array}{l}\text { Poly- } \beta \text {-hydroxybutyrate } \\
\text { accumulation }\end{array}$ & - & - & ND & + & + & - & ND or $\mathrm{V}$ \\
\hline Anaerobic growth & + & - & $\mathrm{v} \dagger$ & + & - & - & $\mathrm{V}$ \\
\hline Nitrate reduction & - & + & $\mathrm{v} \dagger$ & + & + & + & $\mathrm{V}$ \\
\hline Acid from glucose & - & + & $\mathrm{v} \dagger$ & + & - & - & $-\ddagger$ \\
\hline \multicolumn{8}{|l|}{ Hydrolysis of: } \\
\hline Gelatin & - & + & + & - & - & + & $-\S$ \\
\hline Aesculin & + & - & + & - & - & + & -11 \\
\hline DNA G + C content $(\mathrm{mol} \%)$ & 57.8 & $40-42$ & $44-53$ & 51.1 & 49 & 55 & $53-66$ \\
\hline
\end{tabular}

${ }^{*} \mathrm{CR}$, Curved rod; LR, long rod; $\mathrm{R}$, rod; $\mathrm{S}$, spirillum; SR, short rod; TR, thick rod.

$\dagger$. chejuensis is positive and $H$. ganghwensis is negative.

$\ddagger$ Data for $A$. venustensis.

$\$$ Data not available for $A$. jadensis.

IIData for A. borkumensis.

that the coastal marine, oligotrophic isolate cannot be assigned to any previously recognized bacterial family or genus and therefore should be characterized as a novel species within a novel genus, Litoricola lipolytica gen. nov., sp. nov., belonging to a novel family, Litoricolaceae fam. nov.

\section{Description of Litoricola gen. nov.}

Litoricola (Li.to.ri'co.la. L. n. litus -oris seashore; L. suff. -cola from L. masc. or fem. n. incola inhabitant; N.L. fem. n. Litoricola inhabitant of the seashore).

Cells are short rods. Gram-negative. Oxidase-positive and catalase-negative. Chemoheterotrophic and facultatively aerobic. Non-motile. Nitrate is not reduced. Acid is not produced from glucose fermentation. $\mathrm{NaCl}$ is required for growth. The predominant fatty acids are $\mathrm{C}_{16: 1} \omega 7 c$ and/or iso- $\mathrm{C}_{15: 0} 2-\mathrm{OH}, \mathrm{C}_{18: 1} \omega 7 c$ and $\mathrm{C}_{10: 0} 3-\mathrm{OH}$. The DNA $\mathrm{G}+\mathrm{C}$ content of the type strain of the type species is $57.9 \mathrm{~mol} \%$. Phylogenetically, the genus belongs to the family Litoricolaceae within the order Oceanospirillales. The type species of the genus is Litoricola lipolytica.

\section{Description of Litoricola lipolytica sp. nov.}

Litoricola lipolytica [li.po.ly'ti.ca. Gr. n. lipos fat; Gr. adj. lytikos dissolving; N.L. fem. adj. lipolytica fat-dissolving, pertaining to esterase lipase (C8) activity of the species].

In addition to having the properties given in the genus description, the species is characterized as follows. Cells are $0.5-0.7 \mu \mathrm{m}$ wide and $0.8-1.3 \mu \mathrm{m}$ long, dividing by binary fission (see Supplementary Fig. S1, available in IJSEM Online). Colonies on MA are circular, smooth, convex, opaque, cream-coloured and $0.05 \mathrm{~mm}$ in diameter, after 1 week of incubation. Colonies are approximately $1 \mathrm{~mm}$ in diameter after 3 weeks incubation. Growth occurs at 15$30{ }^{\circ} \mathrm{C}$ (optimum, $25{ }^{\circ} \mathrm{C}$ ), $\mathrm{pH} 5-10$ (optimum, $\mathrm{pH} 7.0$ ) and $1.5-10.0 \% \mathrm{NaCl}$ (optimum, 3.0-3.5\% NaCl). No growth is observed at 10 or $35{ }^{\circ} \mathrm{C}$, at $\mathrm{pH} 4$ or 10 or at 1.0 or $15 \%$ $\mathrm{NaCl}$. Aesculin is hydrolysed. $\beta$-Galactosidase activity is present. Negative for indole production, arginine dihydrolase, gelatinase and urease. Only esterase lipase (C8) activity is detected in API ZYM tests; alkaline phosphatase, esterase (C4), acid phosphatase, naphthol-AS-BI-phosphohydrolase, lipase (C14), leucine arylamidase, valine arylamidase, cystine arylamidase, trypsin, $\alpha$-chymotrypsin, 
Table 2. Cellular fatty acid compositions (\%) of strain IMCC $1097^{\top}$ and members of related genera in the order Oceanospirillales

Taxa: 1, IMCC1097 ; 2, Zooshikella (data from Yi et al., 2003); 3, Hahella (Baik et al., 2005); 4, Reinekea (Romanenko et al., 2004); 5, Oleiphilus (Golyshin et al., 2002); 6, Saccharospirillum (recalculated from Labrenz et al., 2003); 7, Alcanivorax (data for A. dieselolei/A. borkumensis/A. venustensis/A. jadensis from Bruns \& Berthe-Corti, 1999; Fernández-Martínez et al., 2003; Liu \& Shao, 2005; Yakimov et al., 1998). For cellular fatty acid analyses, strain IMCC $1097^{\mathrm{T}}$ and members of the genera Zooshikella, Hahella and Reinekea were grown on MA. O. messinensis was grown on ONR7a or SM1 agar medium supplemented with n-hexadecane. S. impatiens was grown on PYGV agar. A. dieselolei was grown on SM1 agar supplemented with alkanes and sodium citrate, A. borkumensis and A. venustensis were grown on SM1 medium supplemented with pyruvate and A. jadensis was grown in an ASW medium (liquid). Only those fatty acids representing at least $5 \%$ of the total cellular fatty acids of at least one of the genera are shown. -, Trace amount or not detected.

\begin{tabular}{|lccccccc|}
\hline Fatty acid & $\mathbf{1}$ & $\mathbf{2}$ & $\mathbf{3}$ & $\mathbf{4}$ & $\mathbf{5}$ & $\mathbf{6}$ & $\mathbf{7}$ \\
\hline $\mathrm{C}_{12: 0}$ & - & - & $1.3-2.4$ & - & - & - & $8.9 /-/ 5.1 / 5.2$ \\
$\mathrm{C}_{14: 0}$ & - & 6.0 & $2.4-2.8$ & 2.0 & 5.5 & - & $-/ 1.1 / 1.4 / 1.7$ \\
$\mathrm{C}_{16: 0}$ & 6.5 & 31.9 & $12.5-18.1$ & 31.6 & 38.6 & 18.9 & $32.1 / 31.5 / 20.2 / 23.4$ \\
$\mathrm{C}_{17: 0}$ & - & - & - & 5.9 & 1.4 & - & $-/-/ 2.8 /-$ \\
$\mathrm{C}_{18: 0}$ & - & - & $1.1-2.8$ & - & 7.7 & - & $-/ 2.0 /-/-$ \\
$\mathrm{C}_{16: 1} \omega 7 c^{\star}$ & $42.8 \dagger$ & 37.1 & $3.3-11.9 \ddagger$ & 26.7 & 16.6 & 21.8 & $11.3 \dagger / 17.1 \S / 15.4 / 13.5$ \\
$\mathrm{C}_{16: 1} \omega 9 c$ & - & - & $3.2-8.8$ & - & 10.9 & - & - \\
$\mathrm{C}_{18: 1} \omega 7 c$ ll & 20.6 & 14.5 & $<1-9.4$ & 19.0 & - & 51.2 & $22.4 / 47.19 / 19.9 / 20.7$ \\
$\mathrm{C}_{18: 1} \omega 9 c$ & - & - & $19.8-39.0$ & - & 1.4 & - & $-/-/ 1.2 /-$ \\
$\mathrm{C}_{18: 3} \omega 6 c$ & - & - & $9.0-10.7$ & - & - & - & - \\
$\mathrm{C}_{19: 0}$ cyclo $\omega 8 c$ & - & - & - & - & - & - & - \\
$\mathrm{C}_{10: 0} 3-\mathrm{OH}$ & 14.1 & 2.1 & - & - & - & - & - \\
$\mathrm{C}_{12: 0} 3-\mathrm{OH}$ & - & 5.1 & $2.5-3.8$ & - & - & - & - \\
$\mathrm{C}_{12: 1} 3-\mathrm{OH}$ & 5.6 & - & - & - & - & - & - \\
$\mathrm{C}_{16: 0} \mathrm{~N}$ alcohol & - & - & $6.5-7.2$ & 1.2 & - & - & - \\
$\mathrm{C}_{17: 0}$ 10-methyl & - & - & $0-14.4$ & - & - & - & - \\
\hline
\end{tabular}

${ }^{*} \mathrm{C}_{16: 1} \omega 7 c$ or $\mathrm{C}_{16: 1} \omega 7 c$-containing fatty acid mixtures.

$\dagger \mathrm{C}_{16: 1} \omega 7 \mathrm{c}$ and/or iso- $\mathrm{C}_{15: 0} 2-\mathrm{OH}$.

$\neq \mathrm{C}_{16: 1} \omega 7 c$ and/or iso- $\mathrm{C}_{16: 0} 2-\mathrm{OH}$.

$\$ \mathrm{C}_{16: 1} \omega 7 c$ and/or $\mathrm{C}_{16: 1} \omega 9 t$.

$\| \mathrm{C}_{18: 1} \omega 7 c$ or $\mathrm{C}_{18: 1} \omega 7 c$-containing fatty acid mixtures.

SOne or more of $\mathrm{C}_{18: 1} \omega 7 c, \mathrm{C}_{18: 1} \omega 7 t, \mathrm{C}_{18: 1} \omega 9 t$ and $\mathrm{C}_{18: 1} \omega 12 c$.

$\alpha$-galactosidase, $\beta$-galactosidase, $\beta$-glucuronidase, $\alpha$-glucosidase, $\beta$-glucosidase, $N$-acetyl- $\beta$-glucosaminidase, $\alpha$-mannosidase and $\alpha$-fucosidase activities are absent. In tests for the utilization of sole carbon sources, positive results are obtained for the following carbon substrates: glycerol, DLglyceraldehyde, D-ribose, L-arabinose, L-rhamnose, D-cellobiose, sucrose, trehalose, D-raffinose, adonitol, myo-inositol, D-xylitol, citric acid, D-glucuronic acid, pyruvic acid, Lalanine, L-histidine, L-lysine, L-ornithine and L-serine. The following carbon sources are utilized weakly: methylamine, ethanol, D-galactose, D-mannose, melibiose, D-melezitose, D-mannitol, gluconic acid, itaconic acid, propionic acid and DL-proline. Methanol, D-xylose, D-fructose, $N$-acetylD-glucosamine, D-glucosamine hydrochloride, D-glucose, $\alpha$-D-lactose, maltose, L-arabitol, D-sorbitol, malonic acid, succinic acid, L-arginine, L-glutamic acid, L-glycine and Lleucine are not utilized as sole carbon sources. Susceptible to chloramphenicol, erythromycin, gentamicin, kanamycin, rifampicin, streptomycin, tetracycline and vancomycin, but resistant to ampicillin and penicillin $G$. The cellular fatty acids are composed of $\mathrm{C}_{16: 1} \omega 7 c$ and/or iso- $\mathrm{C}_{15: 0} 2-\mathrm{OH}(42.8 \%), \mathrm{C}_{18: 1} \omega 7 c(20.6 \%), \mathrm{C}_{10: 0} 3-\mathrm{OH}$ $(14.1 \%)$, an unknown fatty acid (equivalent chain-length $11.799)(6.8 \%), \mathrm{C}_{16: 0}(6.5 \%), \mathrm{C}_{12: 0} 3-\mathrm{OH}(5.6 \%), \mathrm{C}_{10: 0}$ $(0.9 \%), \mathrm{C}_{14: 0}(0.7 \%), \mathrm{C}_{19: 1} \omega 6 c(0.8 \%), \mathrm{C}_{18: 1} \omega 7 c 11-$ methyl $(0.6 \%), \mathrm{C}_{16: 1} \omega 5 c(0.4 \%), \mathrm{C}_{12: 0}(0.1 \%)$ and $\mathrm{C}_{12: 0}$ $3-\mathrm{OH}(0.1 \%)$.

The type strain, IMCC $1097^{\mathrm{T}}\left(=\mathrm{KCCM} 42360^{\mathrm{T}}=\mathrm{NBRC}\right.$ $\left.102074^{\mathrm{T}}\right)$, was isolated from surface seawater off the coast at Goseong, East Sea, Korea.

\section{Description of Litoricolaceae fam. nov.}

Litoricolaceae (Li.to.ri.co.la'ce.ae. N.L. fem. n. Litoricola type genus of the family; -aceae ending to denote a family; N.L. fem. pl. n. Litoricolaceae the family of the genus Litoricola).

The family Litoricolaceae is within the order Oceanospirillales and encompasses Gram-negative bacteria retrieved from marine environments. Currently, the family comprises the genus Litoricola and several uncultured 
marine bacteria. The delineation of the family is primarily determined from the phylogenetic position of the $16 \mathrm{~S}$ rRNA gene sequence. The detailed description is the same as that given for the genus Litoricola. The type genus of the family is Litoricola.

\section{Acknowledgements}

This work was supported by a grant (KRF-2005-0150-c00528) from the Korea Research Foundation funded by the Korean Government (MOEHRD).

\section{References}

Baik, K. S., Seong, C. N., Kim, E. M., Yi, H., Bae, K. S. \& Chun, J. (2005). Hahella ganghwensis sp. nov., isolated from tidal flat sediment. Int J Syst Evol Microbiol 55, 681-684.

Bruns, A. \& Berthe-Corti, L. (1999). Fundibacter jadensis gen. nov., sp. nov., a new slightly halophilic bacterium, isolated from intertidal sediment. Int J Syst Bacteriol 49, 441-448.

Cho, J.-C. \& Giovannoni, S. J. (2003). Parvularcula bermudensis gen. nov., sp. nov., a marine bacterium that forms a deep branch in the $\alpha$ Proteobacteria. Int J Syst Evol Microbiol 53, 1031-1036.

Cho, J. C. \& Giovannoni, S. J. (2006). Pelagibaca bermudensis gen. nov., sp. nov., a novel marine bacterium within the Roseobacter clade in the order Rhodobacterales. Int J Syst Evol Microbiol 56, 855-859.

Fernández-Martínez, J., Pujalte, M. J., García-Martínez, J., Mata, M., Garay, E. \& Rodríguez-Valeral, F. (2003). Description of Alcanivorax venustensis sp. nov. and reclassification of Fundibacter jadensis DSM $12178^{\mathrm{T}}$ (Bruns and Berthe-Corti 1999) as Alcanivorax jadensis comb. nov., members of the emended genus Alcanivorax. Int J Syst Evol Microbiol 53, 331-338.

Franzmann, P. D., Wehmeyer, U. \& Stackebrandt, E. (1988). Halomonadaceae fam. nov., a new family of the class Proteobacteria to accommodate the genera Halomonas and Deleya. Syst Appl Microbiol 11, 16-19.

Garrity, G. M., Bell, J. A. \& Lilburn, T. (2005a). Order VIII. Oceanospirillales ord. nov. In Bergey's Manual of Systematic Bacteriology, 2nd edn, vol. 2, part B, p. 270. Edited by D. J. Brenner, N. R. Krieg, J. T. Staley \& G. M. Garrity. New York: Springer.

Garrity, G. M., Bell, J. A. \& Lilburn, T. (2005b). Family I. Oceanospirillaceae fam. nov. In Bergey's Manual of Systematic Bacteriology, 2nd edn, vol. 2, part B, p. 271. Edited by D. J. Brenner, N. R. Krieg, J. T. Staley \& G. M. Garrity. New York: Springer.

Garrity, G. M., Bell, J. A. \& Lilburn, T. (2005c). Family III. Hahellaceae fam. nov. In Bergey's Manual of Systematic Bacteriology, 2nd edn, vol. 2, part B, p. 299. Edited by D. J. Brenner, N. R. Krieg, J. T. Staley \& G. M. Garrity. New York: Springer.

Golyshin, P. N., Chernikova, T. N., Abraham, W. R., Lunsdorf, H., Timmis, K. N. \& Yakimov, M. M. (2002). Oleiphilaceae fam. nov., to include Oleiphilus messinensis gen. nov., sp. nov., a novel marine bacterium that obligately utilizes hydrocarbons. Int J Syst Evol Microbiol 52, 901-911.

Golyshin, P. N., Harayama, S., Timmis, K. N. \& Yakimov, M. M. (2005). Family II. Alcanivoraceae fam. nov. In Bergey's Manual of Systematic Bacteriology, 2nd edn, vol. 2, part B, p. 295. Edited by D. J. Brenner, N. R. Krieg, J. T. Staley \& G. M. Garrity. New York: Springer.

Kovács, N. (1956). Identification of Pseudomonas pyocyanea by the oxidase reaction. Nature 178, 703.

Labrenz, M., Lawson, P. A., Tindall, B. J., Collins, M. D. \& Hirsch, P. (2003). Saccharospirillum impatiens gen. nov., sp. nov., a novel $\gamma$ Proteobacterium isolated from hypersaline Ekho Lake (East Antarctica). Int J Syst Evol Microbiol 53, 653-660.

Lee, H. K., Chun, J., Moon, E. Y., Ko, S. H., Lee, D. S., Lee, H. S. \& Bae, K. S. (2001). Hahella chejuensis gen. nov., sp. nov., an extracellularpolysaccharide-producing marine bacterium. Int J Syst Evol Microbiol 51, 661-666.

Liu, C. \& Shao, Z. (2005). Alcanivorax dieselolei sp. nov., a novel alkane-degrading bacterium isolated from sea water and deep-sea sediment. Int J Syst Evol Microbiol 55, 1181-1186.

Ludwig, W., Strunk, O., Westram, R., Richter, L., Meier, H., Yadhukumar, Buchner, A., Lai, T., Steppi, S. \& other authors (2004). ARB: a software environment for sequence data. Nucleic Acids Res 32, 1363-1371.

Mesbah, M., Premachandran, U. \& Whitman, W. B. (1989). Precise measurement of the $\mathrm{G}+\mathrm{C}$ content of deoxyribonucleic acid by high-performance liquid chromatography. Int J Syst Bacteriol 39, 159-167.

Ostle, A. G. \& Holt, J. G. (1982). Nile blue A as a fluorescent stain for poly- $\beta$-hydroxybutyrate. Appl Environ Microbiol 44, 238-241.

Prabagaran, S. R., Manorama, R., Delille, D. \& Shivaji, S. (2007). Predominance of Roseobacter, Sulfitobacter, Glaciecola and Psychrobacter in seawater collected off Ushuaia, Argentina, Sub-Antarctica. FEMS Microbiol Ecol 59, 342-355.

Romanenko, L. A., Schumann, P., Rohde, M., Mikhailov, V. V. \& Stackebrandt, E. (2004). Reinekea marinisedimentorum gen. nov., sp. nov., a novel gammaproteobacterium from marine coastal sediments. Int J Syst Evol Microbiol 54, 669-673.

Schäfer, H., Servais, P. \& Muyzer, G. (2000). Successional changes in the genetic diversity of a marine bacterial assemblage during confinement. Arch Microbiol 173, 138-145.

Swofford, D. (2002). PAUP*: phylogenetic analysis using parsimony (* and other methods), version 4. Sunderland, MA: Sinauer Associates.

Yakimov, M. M., Golyshin, P. N., Lang, S., Moore, E. R., Abraham, W. R., Lunsdorf, H. \& Timmis, K. N. (1998). Alcanivorax borkumensis gen. nov., sp. nov., a new, hydrocarbon-degrading and surfactantproducing marine bacterium. Int J Syst Bacteriol 48, 339-348.

Yi, H., Chang, Y. H., Oh, H. W., Bae, K. S. \& Chun, J. (2003). Zooshikella ganghwensis gen. nov., sp. nov., isolated from tidal flat sediments. Int J Syst Evol Microbiol 53, 1013-1018. 